\title{
Career-first: an approach to sustainable labour market integration
}

\author{
Vanesa Fuertes $^{1}\left(\mathbb{D} \cdot\right.$ Ronald McQuaid $^{2} \cdot$ Peter J. Robertson $^{3}$
}

Received: 3 February 2020 / Accepted: 20 November 2020 / Published online: 22 January 2021

(c) The Author(s) 2021

\begin{abstract}
Active labour market policies aim at supporting people entering and, importantly, remaining in the labour market. Initiatives to this end have often been characterised by a mixture of 'human capital' and 'work-first' approaches, although both have had a relatively limited effect on achieving job sustainability for those most distant from the labour market. This paper explores a distinctive approach to supporting job entry and sustainable employment that we have called 'career-first'. The career-first approach to labour activation draws on three separate traditions of thinking: labour market, career development, and the capability literatures. Common ground is found in these three perspectives so each complements the weaknesses of the others. A career-first approach may be able to help deliver benefits to the individual, their family, and the wider society.
\end{abstract}

Keywords Employability · Career-first · Capability

\section{Résumé}

« La carrière d'abord» : une approche pour une intégration durable sur le marché du travail Les politiques du travail actuelles visent à aider les personnes à entrer et à se maintenir dans le marché du travail. Ces initiatives se caractérisent souvent par un mélange d'approches basés sur le "capital humain" et sur le "travail d'abord", bien que ces deux approches aient eu un impact limité sur la durabilité de l'emploi pour les personnes les plus éloignées du marché du travail. Ce document explore une nouvelle approche de soutien à l'entrée sur le marché du travail et à l'emploi durable, appelée "la carrière d'abord". L'approche «la carrière d'abord»s'appuie sur les points forts et évite les faiblesses de trois traditions : le marché du travail, le développement de

Vanesa Fuertes

vanesa.fuertes@uws.ac.uk

1 School of Education \& Social Sciences, University of the West of Scotland, Elles Building East - L104c, High Street, Paisley PA1 2BE, Scotland, UK

2 Stirling Management School, University of Stirling, Stirling, Scotland, UK

3 School of Applied Sciences, Edinburgh Napier University, Edinburgh, Scotland, UK 
carrière et la littérature sur les capabilités. Cette approche peut contribuer à améliorer les avantages pour l'individu, sa famille et, dans un sens plus large, la société.

\section{Zusammenfassung}

"Career-first": Ein Ansatz zur nachhaltigen Integration in den Arbeitsmarkt Die derzeitige Arbeitsmarktpolitik zielt darauf ab, Menschen zu unterstützen, in den Arbeitsmarkt einzutreten und dort auch zu verbleiben. Die Initiativen zeichnen sich häufig durch eine Mischung aus "Humankapital"- und "Work-first"-Ansätzen aus, obwohl beide nur einen begrenzten Einfluss auf die Nachhaltigkeit der Arbeitsplätze von Personen haben, die am weitesten entfernt sind vom Arbeitsmarkt. Dieses Papier untersucht einen neuen Ansatz zur Unterstützung des Berufseinstiegs und der nachhaltigen Beschäftigung, der als "Career-first" bezeichnet wird. Der "Careerfirst"-Ansatz zur Aktivierung von Arbeitskräften stützt sich auf die Stärken dreier Traditionen und vermeidet gleichzeitig deren Schwächen: Arbeitsmarkt, Laufbahnentwicklung und Fähigkeitsliteratur. Ein "Career-first"-Ansatz kann dazu beitragen, den Nutzen für den Einzelnen, seine Familie sowie die Gesellschaft zu verbessern.

\section{Resumen}

Career-First: Un enfoque para una integración duradera en el mercado del trabajo Las actuales políticas laborales tratan de ayudar a las personas a entrar y permanecer en el mercado del trabajo. Estas iniciativas se caracterizan a menudo por una combinación de los modelos del "capital humano" y "work-first", aunque ambos modelos han tenido un impacto limitado sobre la sostenibilidad del empleo para las personas más alejadas del mercado laboral. Este artículo explora un nuevo enfoque para apoyar la inserción laboral y el mantenimiento del empleo, denominado "Career-first". El enfoque "Career-first" para la activación laboral se apoya sobre los puntos fuertes y evita las debilidades de tres posturas tradicionales: la literatura sobre el mercado laboral, el desarrollo de la Carrera y las capacidades. El modelo "Careerfirst" puede contribuir al incremento de beneficios para el individuo, la familia y la sociedad en general.

\section{Introduction}

Labour market policy scholars point to a relatively recent change in the welfare state paradigm towards what has been labelled activation (Cantillon, 2011), which continues the trend seen in previous unemployment schemes of conditionality and behavioural expectations of those unemployed (Sinfield, 2001). Active labour market policies aim to support people entering and remaining in the labour market (see Kluve, 2010 for a review of EU policies), at the same time introducing a redefinition of the perception, the solutions, and the resources invested in dealing with unemployment. Activation policies put greater emphasis on individual responsibilities and obligations, widen the activation target group, and integrate income protection measures and labour market activation programmes (van Berkel \& Borghi, 2007). Recent UK activation measures have reclassified previously economically inactive individuals 
as unemployed and have introduced harsher sanctions with new responsibilities of compliance with activation rules for those furthest from the labour market (Fuertes \& Lindsay, 2016).

The two dominant activation approaches that might be found in combination have been described as 'human capital' and 'work-first' (Dean et al., 2005; Lødemel \& Trickey, 2001). Human capital is embedded in the notion of increasing and updating a person's skills and training to match labour market demand (Lindsay, 2014). Work-first approaches, which in recent decades have largely driven labour market policy (HM Government, 2010; McQuaid \& Lindsay, 2009), are concerned with rapid labour market entry (Bivand et al., 2006) with limited consideration given to the quality or suitability of paid employment (Daguerre, 2007). While moving into paid employment is seen as the main way out of poverty for working-aged unemployed people, activation measures have been criticised for sometimes resulting in low-pay no-pay cycles, and in-work poverty (McQuaid et al., 2010; Shildrick and MacDonald 2012). Even though the Work Programme- the UK national welfare-towork initiative from 2011 to 2017-represented an explicit attempt at achieving job sustainability for the long-term unemployed, it had limited success, particularly for groups such as those further away from the labour market and those with disabilities (Brown et al., 2018).

This paper proposes and explores a 'career-first' approach to labour market inclusion first mentioned by McQuaid and Fuertes (2014), which is described, without fully operationalising it, as an approach to labour market inclusion with a focus on the quality of jobs, job progression and longer-term career progression. Our aim is to develop this approach, situating it beyond the work-first and human capital approaches. The career-first main aim is achieving job entry and subsequent employment sustainability for those seeking to enter the labour market, especially those furthest from the labour market. In this paper, we present the career-first concept as underpinned by three literatures that have been largely disconnected: the labour market, career development, and capability literatures. Bringing together factors at the macro-, micro-, and meso-level from these literatures could help to achieve sustainable labour market integration. The paper is structured in three sections. First, UK labour market inclusion approaches are presented. This is followed by a brief exploration of the concept of employability from the perspective of the labour market, career development, and capability literatures. The paper concludes with a discussion section of the career-first concept.

\section{Labour market inclusion approaches}

Two approaches are usually displayed in active labour market initiatives: human capital and work-first. Human capital can be described as embedded in the notion of increasing and updating a person's employability, largely via education and training (Lindsay et al., 2007) to match labour market demand, by often offering substantial and sometimes quite long-term support. The European Union economic strategies have tended to speak of human capital as a mixture of skills and active labour market measures, "so as to maximize the employability and adaptability of workers", 
with an emphasis on personalised and effective support (European Commission, 2019). Although in the UK, according to Dean et al. (2005), human capital reflects a self-development strategy of building portfolios of often meaningless qualifications and the re-crafting of curriculum vitae.

In recent decades, labour market policy has been largely driven by work-first approaches focused on rapid labour market entry with those unemployed being encouraged to take any job as quickly as possible (Lindsay, 2014), which has led to employability support mostly aimed at job search assistance and mainly achieving skills for entry-level jobs, with insufficient regard for future progression, job satisfaction, and long-term employment stability. This approach, typically delivered by service providers' contractual 'payment by result' models, has been criticised for encouraging revolving doors of unemployment, 'creaming' off those who are most job-ready, and 'parking' of those farthest away from the labour market (Berry, 2014; Lindsay et al., 2007).

Nonetheless, recent activation initiatives have tried to tackle perverse incentives and achieve sustainability of labour market entries, even if not necessarily successfully for those furthest from the labour market, through for instance the staggered and differential payments in the UK Work Programme. Sustainable employment has been defined as remaining in work, either in one job or by moving to other jobs that provide opportunities to advance and earn more (National Audit Office, 2007). Achieving sustainable employment could decrease benefit spending, increase efficiency of welfare-to-work programmes, and reduce staff turnover. However, the Work Programme only represented a partial view of sustainability, measured as length in employment, and therefore, can only be regarded as an incipient stage towards sustainable labour market policies (McQuaid \& Fuertes, 2014). Sustainability measures need to be further developed, so as to take greater account of the quality and suitability of employment (e.g. in terms of suitable income, working conditions, travel to work, etc.), opportunities for progression, and indeed the longer-term career path of the unemployed person. This would reflect a move from a work-first or human-capital policy orientation towards a more sustainable career-first approach.

There is a range of factors that might improve sustainability of employment: adequate financial rewards; relevant skills; adequate communication, attitudes and work-related aspirations; distance of travel; accessibility of suitable support, such as childcare, local transport and social networks; job terms and conditions of the work contract, e.g. hours of work; employer attitudes; good jobs where people feel valued, rewarded, and engaged. Activation initiatives usually do not aim to influence employers (Ray et al., 2009) in terms of the recruitment, sustainability of job (e.g. conditions and rewards) and decent employment, even when a number of scholars have recognised the importance of employers in activation policy (Ingold \& Stuart, 2015). Rather, they are often aimed at increasing the individual's employability and/ or adaptability to the labour market.

Employability can be defined, sometimes tautologically, as the ability or capacity of an individual to attain and sustain paid employment (McArdle et al., 2007); nevertheless, an individual can be employable even though presently unemployed. In its efforts to reduce the rate of unemployment, increasing employability has been the focus of the UK Department for Work and Pensions. Even though employability 
has been a concept used in the labour market and career studies, and recently in the capabilities field, these literatures have not fully integrated each other's developments. We explore this concept and each of these literatures next.

\section{Labour market policy literature}

Labour market policy literature has focused on unemployment, economic inactivity, low-paid employment, and income insecurity, analysing its causes and the various government policy tools to tackle and prevent these events. The literature stresses the increase in conditionality of income transfers or in-kind benefits (passive policies) on participation in active labour market policies. Active policies are focused on increasing people's employability (i.e., supply side policies) or on influencing the labour demand (i.e., demand-side policies) by increasing the supply and accessibility of jobs in general or for specific target groups (e.g. Martin \& Grubb, 2002). Employability in this literature, especially in government papers, was often, and still is in some cases, defined as personal characteristics such as qualities and skills (Yorke, 2006), putting, therefore, the responsibility of being employable on individuals' characteristics and skills. The discourse on employability changed significantly after McQuaid \& Lindsay's (2005) development of their broad employability framework, where employability encompasses individual characteristics and circumstances and broader external social, institutional, and economic factors. Their model supported the discourse that stressed the need for a holistic view of unemployment, with demand- and supply side broad policies implemented in tandem.

Supply side policies used a work-first and/or a human capital approach to supporting individuals' employability. The literature shows that human capital approaches achieve better performance in the long-term (see e.g. Card et al., 2010; Dyke et al., 2006), higher retention of jobs and in-work progression (Peck \& Theodore, 2001), and facilitates a discourse of higher wages when in work and higher returns to the economy. This approach necessitates the use of professional workers, but not necessarily career advisers, advising on appropriate learning and development opportunities. However, Dean et al. (2005), highlights that this support in the UK tends to provide low quality skills and training. Human capital approach is underpinned by a belief in the supply of and aspiration to 'better' jobs after individual betterment, rather than achieving better pay and conditions in existing jobs. These narratives, together with the emphasis on individual responsibility and flexibility, highlight the neoliberal slant within the human capital discourse (Nunn, 2019).

However, work-first initiatives tend to achieve better job outcomes (Finn \& Schulte, 2008). This, alongside the work ethic or dependency discourse, and pressures on government to reduce expenditure on out-of-work benefits, have encouraged the dominance of the work-first approach in activation initiatives. Usually, work-first uses sanctions rather than relying on trust (Sol \& Hoogtanders, 2005). There has been criticism of work-first approaches from analysis that link causes of unemployment to structural factors. For instance, a number of authors distance their work from the individualist discourse of activation, by stressing that there are regional inequalities with regards to unemployment (Beatty \& Fothergill, 2017; 
Fletcher, 2007), that unemployed and employed individuals have similar attitudes and aspirations (Fletcher, 2007), and that there is an absence of inter-generational cultures of worklessness (Shildrick et al., 2012b).

Research on current activation trends suggests a focus on individual characteristics and behaviour, increased conditionality (Dwyer and Wright, 2014), more common and longer sanctions, and wider reach of activation policies. Activation is supported by the paternalistic justifications regarding the benefit of paid employment, and by the work ethic rhetoric or dependency discourses that see a lack of individual motivation as a key cause of unemployment (Deeming, 2015; Mead, 2003). This is used to justify the use of conditionality, sanctions, and 'carrots and sticks' (Castonguay, 2009) to encourage the expected behaviour (Dean, 2007; Patrick, 2012). Berry (2014) points out that activation is part of the framework that gives rise to certain labour market forms rather than just being a response to labour market conditions. The literature has focused increasingly on the effects of activation measures, not only on job outcomes, but also on individual's wellbeing and on poverty levels. Research indicates mixed impacts of activation schemes on participants' well-being, albeit dependent on the type of activation (Carter \& Whitworth, 2017). Some scholars argue that conditionality intensifies poverty and disadvantages for those with greater need for support, without increasing job uptake (Wright \& Patrick, 2019). The Work Programme's limited achievements on job sustainability and personalised support was due to cost pressures and ambitions performance targets (Rees et al., 2014), in part a result of the limited level of resources committed to activation policies and to the contractual model used.

\section{Career development literature}

The career development literature is multi-disciplinary, drawing heavily on psychology, sociology and other social sciences. The field can be briefly summarised as three discourses, relating to (i) organisational careers, (ii) career education and counselling, and (iii) socio-political perspectives.

The organisational careers discourse, in its earlier manifestations, focused on how adult workers forged careers within the context of large and stable employers. The discourse subsequently shifted to explore how organisations and individuals can and should respond to disruptive change in labour markets (notably Arthur \& Rousseau, 1996; Hall, 2004). This literature focuses primarily on managerial and professional roles; unemployed, lower paid, and marginal workers are neglected. As a result, it rarely addresses issues of welfare-to-work. The radical transformation of modern work is the starting point for most arguments, although the underpinning labour market analysis is limited or serves only to support the assumption of uncertainty. Mackenzie Davey (2020) argues this perspective has tended to take concepts relevant to specific types of workers at specific times (e.g. managers in unstable labour markets) and to overgeneralise them. In consequence, individual agency is overestimated and recommendations for individuals to take control of, and responsibility for, their careers have tended to become overly prescriptive. 
The second discourse relates to career education and counselling interventions, with a focus on the use of techniques to support both young people and adults, underpinned by a diversity of psychological theories (e.g. Arthur et al., 2019). Early approaches drew heavily on matching individuals to suitable employment by use of psychological assessment techniques to generate occupational recommendations, while non-directive and quasi-therapeutic counselling approaches later became influential (Kidd, 2006). This extensive literature applies varied and sophisticated analysis to interactions between service users and helping professionals. In recent years, this discourse has become heavily influenced by the parallel discourses of labour market turbulence. The belief that the nature of employment is 'fluid' has been used a justification for the adoption of 'new paradigm' (postmodern and constructivist) approaches (Maree, 2010; McMahon \& Patton, 2006; Savickas \& Porfeli, 2012), a feature in stark contrast to the labour market literature. The development of the construct of career adaptability (Savickas \& Porfeli, 2012), and the identification of psychological resources (Hirschi, 2012) to cope with change, are examples of twenty-first century career counselling concepts that show the influence of the organisational career concepts.

An educational subset of this discourse conceptualises helping as supporting the process of career learning (e.g. Barnes et al., 2011). This is pertinent to groups of students in schools, colleges and universities in transition to the labour market, but can also be applied to workers and job seekers in community settings. In recent years notions of teaching transferable career management skills have been prominent. This is evident in the international spread of career management competency frameworks (Hooley et al., 2017). This approach seeks to address the acquisition of skills for making multiple transitions and navigating an unpredictable labour market.

Thus, some elements of the career development literature are rich in psychological and educational approaches. The concept of employability is influential and has become synonymous with flexibility and adaptability (e.g. Fugate et al., 2004; McArdle et al., 2007). The focus is on developing attributes of the individual that are desirable to employers and adaptive to labour market conditions. However, these perspectives tend to neglect wider socio-economic and contextual factors. These concerns are addressed in the third discourse.

The socio-political discourse is multi-disciplinary and multi-level in character. Sociological critiques of the individualism of psychological explanations of career choice and development are well established, and alternative structural explanations are available (notably Roberts, 2009). Approaches that emphasise social justice and support for disadvantaged groups have grown in prominence in the career development literature (Blustein, 2006; Irving, 2005). An international public policy literature addressing career development is now available (e.g. OECD, 2004; Watts, 2008). This discourse highlights the role of career guidance in improving efficiency at the interface between supply and demand in the labour market, and the interface between the education and employment systems in society. It links career development to lifelong learning policy, offering an economic rationale for career guidance through its potential to support states to build human capital in their populations and to compete internationally on skills. The economic rationale is balanced by a social 
equity rationale for career development interventions, which are seen to have a role in the fair allocation of life chances.

While some voices adopt this human capital development perspective, others prefer a more radical social justice agenda. There has been growing uneasiness with dominant career development discourses that place the responsibility on individuals (not on institutions) to respond to labour market change, and produce prescriptions for individuals to transform themselves into compliant flexible workers. This has generated anxiety that career development practices can be hijacked by a neoliberal agenda (Hooley et al., 2017). This concern is directly relevant to the use of career guidance practices in welfare-to-work programmes (Nunn, 2019).

\section{The capability literature}

Sen's capability approach, initially developed to evaluate human wellbeing, development and justice (Laruffa, 2019), is concerned with people's freedom of choice with regards to what they can do (Dean et al., 2005), taking into account external factors and personal characteristics (Sen, 1985a, b). It sees the individual as autonomous and able to decide based on their understanding of a 'good life' (Deneulin, 2011) and provides normative principles for action based on freedom, well-being and agency (Deneulin, 2014). Sen argues that equal inputs do not result in equal outputs (functionings), since functionings are mediated by a range of factors (socio-economic, cultural or historical, and geographical or climatic) which are our capabilities for action (Dean et al., 2005). Although Sen did not fully explain what human capabilities consists of, he did stress that it depends of a variety of factors including personal characteristics and social arrangements.

To measure capabilities, Chiappero-Martinetti et al. (2015) state the need to look at agency-autonomy-empowerment and poverty and well-being (Sen appears to link capabilities with well-being). Research on capabilities has to go beyond the usual focus on functioning space since, as Zimmermann (2006) points out, looking at the actual outcome of an activity (education or work) is looking at functionings rather than capabilities, which would entail looking at the opportunity to achieve something (work or education). Some authors have developed a capability list (e.g. Nussbaum, 2011) or capability requirements, such as Burchardt and Vizard (2011) or Hollywood et al. (2012, p. 6), who considered resources, empowerment, individual conversion factors, and external conversion factors. Bonvin and Farvaque (2005) argue that public policies are critical in facilitating the development of capabilities, which encompass individual situations, trajectories and potentialities, and the efficiency and fairness of social structures and arrangements (all of which can be shaped by public policies). Therefore, labour market policies would be essential to the capabilities for work and to employment outcomes.

The capability approach shares similarities with other frameworks, such as human needs or human rights theory, and although it was originally employed in economics, it has been used in various policy fields, including career guidance (Robertson, 2015) and employment (e.g. Egdell \& McQuaid, 2016). Application of the capability approach to labour market policy would mean that activation initiatives empower 
recipients and allow them to choose their way of living, instead of being paternalistic tools. Empowerment is operationalised as adequacy of the measure, availability of resources, and eligibility criteria. As Bonvin and Farvaque (2005, p. 126) stress, capability of work is about 'the real freedom to choose the work one has reason to value' and recognising that paid employment could be a disutility and valueless and, therefore, the person has to be able to refuse or transform it into something one has reason to value. Although, the capability approach acknowledges that constraints cannot be completely eradicated, a fair and negotiated construction of this constraint is necessary (Bonvin \& Farvaque, 2006).

According to Dean et al. (2005, p. 10), a government that could be classified as 'capability state' is one which may not allow 'complete freedom of choice' to the job seeker, but would still enhance internal capabilities, and allow voice to the job seeker's aspirations with a view to 'realising combined capabilities'. The informational basis of interventions would be determined by local institutions mediating rather than prescribing, with jobseekers formulating, arguing and realising their life plans (Dean et al., 2005). This type of capability approach requires 'situated' public action or 'situatedness' (Bonvin \& Farvaque, 2005) which is contrary to hierarchical governance and implies that the job-seeker and the frontline worker are actors in the activation and labour market regulation process, respectively. Bonvin \& Farvaque (2005) called this capability for voice, stressing that it does not imply the disappearance of central intervention but requires that local actors have voice during all stages of the policy process. Finally, addressing environmental conversion factors, such as the number and types of jobs available or corporate social responsibility, is key to the capabilities approach, and is another factor that differentiates it from the human capital theory (Zimmermann, 2006).

\section{The career-first approach: integrating the three literatures}

The career-first concept positions itself beyond the work-first and the human capital perspectives. The career-first approach focuses on employment sustainability by achieving an employment status and trajectory that the individual has a reason to value and is willing and able to choose. Career-first is about the integration of career guidance and the capability approach to labour market policy. The approach takes into account individual skills and characteristics, motivation and attitude, and flexibility and adaptability; but stresses the interrelation between the socio-economic environment and individual characteristics, and highlights the importance of providing professional advice and support, information and deliberation, and voice and agency.

The career-first practice needs to provide professional expertise and information on the labour market and career development, alongside acknowledgement, consideration of, and an aim to change constraining environmental factors. In other words: it is the integration of suitable support and decent work, career guidance in its broadest sense, and capability. The career-first approach to employment activation would allow individuals the space and access to the resources necessary to achieve their capabilities and have a choice in relation to work. Therefore, obligation 
or 'adaptive preferences' which are decisions made in an environment of restricted options (Bussi \& Dahmen, 2012), are not necessarily compatible with choice.

The following themes bring together these three literatures to help build the career-first approach, both in theory and practice.

\section{Techniques, relationships and professionalism}

Labour activation devotes limited attention to technical resources or career development as a factor of employability. Sometimes career development is subsumed under or conflated with vocational education and training policy, which, although potentially inter-related, are distinct elements. In contrast, the career development literature encompasses an extensive range of assessment, counselling and educational approaches for use in individual, group, or online service delivery. The use of a wide range of techniques implies practitioners' depth of training and expertise. These approaches are largely ignored in activation settings, and providers have tended not to rely extensively on professionally trained or qualified staff. Experiences of unemployed individuals when participating in labour market initiatives with various service providers, have been extensively documented by the labour policy literature.

In several nations, including the UK, career guidance services have had a key role in preventing and remedying youth unemployment, but their involvement in labour activation for adult unemployed groups has been limited. In nations where career guidance takes place within the context of public employment services (PES) (see Watts \& Sultana, 2004), it is not without challenges. This is due to the potential conflict between the professional ethics, non-directive, person-centred values of career development practitioners, and the work practices of PES organisations which may be driven by job placement targets or enforcement of welfare benefit regulations. Career development practices may become superficial, revealing "PES career guidance to be the rather thin silk glove covering the iron fist of disciplinary conditionality..." (Nunn, 2019, p. 174).

The identity and expertise of the staff delivering activation initiatives has implications for the relevancy and accuracy of support provided, as well as for the relationships created. The interactions between street-level bureaucrats and service users can shape the outcomes of employment interventions. Within a career-first approach, activation programmes would be a very appropriate arena for the application of career development techniques. A fully effective use of career development would require the employment of career professionals, and a deeper embedding of its principles and practices into the design and goals of labour market initiatives. The importance of professional labour market information and career guidance to achieve sustainable entries into the labour market has not been fully considered within activation policies and the employability framework.

\section{Responsibility and values}

Activation policies focus on the responsibility and duty of the individual for labour market participation (Ray et al., 2009). The role of the state has been to use both 
'carrots and sticks' with primarily an economic aim. Activation policies place the responsibility of unemployment primarily on the characteristics, skills, and behaviour of the unemployed person; while the broader labour market literature stresses the key influence of external and structural factors on unemployment, including employers' attitudes and employment conditions. In the capability approach, Sen encompasses a clear sense that humans must be seen as moral entities, not as instruments for an economic purpose, in clear opposition to most activation policies and somewhat closer to the career guidance stance. The capability approach takes account of the influence of external factors including public policy on the opportunities (capabilities) to achieve employment outcomes (functionings).

The career development profession provides a more micro-level morality: work with clients is based on a respect for self-determination that is infused with a humanistic philosophy with roots in person-centred counselling (e.g. Rogers, 1951). Career development professionals work to codes of ethics that highlight a respect for individual autonomy (e.g. CDI, 2014). At the same time, the career development literature has paid limited attention to the role of contextual and structural factors for disadvantaged individuals (the labour market literature can contribute to this understanding). In recent years, there have been attempts to apply the capability approach to career development (e.g. Picard et al., 2015; Robertson, 2015; Robertson \& Egdell, 2018), demonstrating that this approach can provide a useful perspective on the career experiences of a variety of groups, and can describe the impact of career development services. However, a detailed prescription for applying the capability perspective has not yet being presented-which perhaps partly reflects the abstract nature of Sen's conception.

The career-first approach embraces the broad employability framework from the labour policy literature, together with the incipient understanding of the role of social institutions in career development, and the mediating factors (necessary to achieve capabilities) in the capability approach. This institutional and structural perspective is complemented by the role of skills and education on career opportunities and the experiences and impact of various services on individuals. Career professionals working in activation policies should be able to have regard within their guidance for these various constraining/mediating factors, and should be involved in contributing and shaping local policy and activation initiatives.

\section{Voice, (constrained) freedom, and long-term perspective}

The capability approach does not limit the notion of 'beings and doings' to formal paid employment and this allows for a wider range of life roles to be considered. Emphasis is placed on facilitating people to access work and activities that they have reason to value. This means developing societal arrangements that facilitate people being able to lead lives that are personally meaningful. This is contrary to seeing individuals primarily as economic resources to be deployed by society in pursuit of a macro-level goals. What is valued is an individual or community judgement made within the context of a local culture, for deciding what a good life is. This criteria or judgement cannot be set by governments or higher authorities. 
It is only recently that labour market literature has paid attention to the relevance of the capability approach for labour market transitions and sustainability. Human capital has been, in some instances, inappropriately conflated with Sen's human capabilities (Dean et al., 2005). Although human capital approaches, such as the provision of skills training, could increase a person's functioning, it would not necessarily provide human capability. The focus should be on individuals' value decisions, freedom of choice, and access to resources (Egdell \& McQuaid, 2016). An approach focused on service users' voice in the design and implementation of policies in this area (Egdell \& Graham, 2017) and agency in the choice of work people value (Bonvin \& Farvaque, 2005) has been proposed as an alternative framework to pursue activation.

Voice is deeply embedded in career development practice, due to its roots in person-centred counselling which emphasises listening and understanding (including preferences, interests and aspirations) as accurately as possible. Voice is also present in relation to advocacy, seeking to use professional skills, and authority to amplify the service user perspective. However, the service user's voice is typically contained within the guidance interaction, rather than contributing to the design and governance of services (this topic is explored by Plant \& Haug, 2018). It is important, however, that career development work is not reduced to solely talent matching (although that may be one aspect of it); it also involves identifying what is important to individuals, clarifying their values, and enabling people to develop and implement lifestyles that are consistent with those values. Since the seminal work of Donald Super (e.g. Super, 1980; Super et al., 1996), career development has been able to encompass a full range of life roles including worker, student, parent, homemaker, 'leisurite', and community member. Decisions about work are made in the context of a wider network of social relationships. Super introduced a 'life-span, life space' perspective which allowed not just for multiple life roles and social identities but also for the overlap and evolution of those roles with maturation through the entire life-span. The importance of a career that is sustainable over time is implicit throughout the career development literature, but has more recently been made explicit, notably in the work of De Vos et al. (2016). This sense of a time perspective, most particularly a long-term perspective, is generally lacking in the capability approach (Robertson, 2015).

In the capability approach, the notion of agency is the person's freedom to pursue and achieve their goals or values (Sen, 1985b). This is one of the most difficult areas for welfare-to-work provision, where relatively little attention is paid to life roles outside of formal employment and time frames considered are largely short-term. While activation is currently focused on entry into paid employment, if sustainability is to be achieved, people's choices (that they have reason to value) need to be considered, even if within a broad and long-term work-framed environment.

Career-first activation would embed jobseekers' choice of work that they value, and would take into account external conversion factors which are fundamental in shaping jobseekers' choice. Some scholars argue that taking this approach to employment policy would mean that individuals would also be able to choose options such as volunteering (Orton, 2011). For other authors, however, the end goal would be to individualise policies so they promote people's proper choice and 
freedom (Bonvin \& Farvaque, 2005). Egdell \& Graham (2017) provide an overview of the applications of the capability approach in activation policy, including a few critiques. The career-first approach proposed encompasses the capability approach's "real freedom to express one's wishes, expectations, desires, etc. and make them count" (Schröer, 2015, p. 369). Although constraints cannot be completely eliminated, the career-first approach should acknowledge and negotiate these constraints. However, low levels of welfare benefits or sanctions would undermine the freedom to choose.

\section{Conclusions}

A career first approach to labour activation can be seen to draw on three separate traditions of thinking-labour market studies, career development, and the capability approach. Common ground can be found in these three perspectives and each can complement some of the weaknesses of the others. By combining these viewpoints, we can identify features of a career-first approach to labour market (re)integration, that support long-term employment offering real opportunities for progression that is distinctive in various ways from the work-first and human capital approaches:

- Support to enable individuals to identify what is important to them, and to clarify how to implement their values as a lifestyle, albeit within societal constraints.

- Support to enable individuals to identify the resources available to them, to develop those resources, and to convert those resources into valued lifestyles.

- Services delivered by staff with a level of training and qualification commensurate with the use of career assessment, counselling and educational techniques required to support people into sustainable work and lifestyles.

- Staff development that helps promote relationships with service users that are underpinned by respect for individual autonomy and values.

- Regimes of service funding that encourage the above (e.g. stable professional services, long-term and service user values).

- Service users who are involved in the design, governance and evaluation of services.

- A focus on outcomes that are personally meaningful, and valued by individuals. Outcomes will often include, but are not limited to, paid formal employment. Study, caring and other life roles should also be encompassed.

- A focus on moving towards long-term sustainable lifestyles built on decent work, i.e., employment that is adequately paid, healthy and secure and offers opportunities for development for those who wish it.

This paper intends to provide some ideas to begin a conversation on the feasibility and desirability of a career-first approach to employability. There are many areas to be debated. One of them is the subjective nature of many of the concepts used above, such as what is understood as a good job or a good outcome. Resource constraints on the development and implementation of policies will play an important part in how effective such an approach might be. However, these 
challenges are not insurmountable, since, for instance, there is an increasing body of literature that defines decent work. One factor to be addressed is the corporate social responsibility of employers and their responsibility and interest in supporting career-first and good jobs, and the support that can be offered to achieve this.

The state of the labour market and the type of economy that we are aspiring to live in must also be considered. A career-first rather than work-first approach to the labour market, with jobs worth having, will be able to deliver benefits to the individual, their family and the wider society.

Funding Not applicable.

\section{Compliance with ethical standards}

Conflict of interest The authors declare that they have no conflict of interest.

Open Access This article is licensed under a Creative Commons Attribution 4.0 International License, which permits use, sharing, adaptation, distribution and reproduction in any medium or format, as long as you give appropriate credit to the original author(s) and the source, provide a link to the Creative Commons licence, and indicate if changes were made. The images or other third party material in this article are included in the article's Creative Commons licence, unless indicated otherwise in a credit line to the material. If material is not included in the article's Creative Commons licence and your intended use is not permitted by statutory regulation or exceeds the permitted use, you will need to obtain permission directly from the copyright holder. To view a copy of this licence, visit http://creativecommons.org/licen ses/by/4.0/.

\section{References}

Arthur, N., Neault, R., \& McMahon, M. (2019). Career theories and models at work: Ideas for practice. CERIC.

Arthur, M. B., \& Rousseau, D. M. (1996). Introduction: The boundaryless career as a new employment principle. In M. B. Arthur \& D. M. Rousseau (Eds.), The boundaryless career: A new employment principle for a new organizational era (pp. 3-20). Oxford University Press.

Barnes, A., Bassott, B., \& Chant, A. (2011). An introduction to career learning and development 11-19: Perspectives, practice and possibilities. Routledge.

Beatty, C., \& Fothergill, S. (2017). The impact on welfare and public finances of job loss in industrial Britain. Regional Studies, Regional Science, 4(1), 161-180. https://doi.org/10.1080/21681 376.2017.1346481.

Berry, C. (2014). The hyper-Anglicisation of active labour market policy. Sheffield Political Economy Research Institute, SPERI Paper 14.

Bivand, P, Brooke, B., Jenkins, S. \& Simmonds, D. (2006). Evaluation of the StepUp Pilot: Final Report, Research report 337. Department for Work and Pensions.

Blustein, D. (2006). The psychology of working: A new perspective for career development, counseling, and public policy. Lawrence Erlbaum.

Blustein, D. L., Medvide, M. B., \& Wan, C. M. (2012). A critical perspective of contemporary unemployment policy and practices. Journal of Career Development, 39(4), 341-356. https://doi. org/10.1177/0894845310397545.

Bonvin, J. M., \& Farvaque, N. (2005). What informational basis for assessing job-seekers?: Capabilities vs. preferences. Review of Social Economy, 63(2), 269-289. https://doi.org/10.1080/00346 76500130614 
Bonvin, J. M., \& Farvaque, N. (2006). Promoting capability for work: The role of local actors. In S. Deneulin, M. Nebel, \& N. Sagovsky (Eds.), Transforming unjust structures the capability approach (pp. 121-142). Springer.

Brown, J., Katikireddi, S. V., Leyland, A. H., McQuaid, R., Frank, J., \& Macdonald, E. B. (2018). Age, health and other factors associated with return to work for those engaging with a welfareto-work initiative: A cohort study of administrative data from the UK's Work Programme. British Medical Journal Open, 8(10), 786-792. https://doi.org/10.1136/bmjopen-2018-024938.

Burchardt, T., \& Vizard, P. (2011). "Operationalizing" the capability approach as a basis for equality and human rights monitoring in twenty-first-century Britain. Journal of Human Development and Capabilities, 12(1), 91-119. https://doi.org/10.1080/19452829.2011.541790.

Bussi, M., \& Dahmen, S. (2012). When ideas circulate. A walk across disciplines and different uses of the "capability approach". Transfer: European Review of Labour and Research, 18(1), 91-95. https://doi.org/10.1177/1024258911433541.

Cantillon, B. (2011). The paradox of the social investment state: Growth, employment and poverty in the Lisbon era. Journal of European Social Policy, 21(5), 432-449. https://doi.org/10.1177/09589 28711418856.

Card, D., Kluve, J., \& Weber, A. (2010). Active labour market policy evaluations: A meta-analysis. The Economic Journal, 120(548), F452-F477. https://doi.org/10.1111/j.1468-0297.2010.02387.x.

Carter, E., \& Whitworth, A. (2017). Work activation regimes and well-being of unemployed people: Rhetoric, risk and reality of quasi-marketization in the UK work programme. Social Policy \& Administration, 51(5), 796-816. https://doi.org/10.1111/spol.12206.

Castonguay, J. (2009). Benchmarking carrots and sticks: Developing a model for the evaluation of workbased employment programs. Amsterdam University Press.

CDI (2014). Code of ethics. Career Development Institute.

Chiappero-Martinetti, E., Egdell, V., Hollywood, E., \& McQuaid, R. (2015). Operationalisation of the capability approach. In H. U. Otto, et al. (Eds.), Facing trajectories from school to work (pp. 115139). Springer.

Daguerre, A. (2007). Active labour market policies and welfare reform: Europe and the US in comparative perspective. Palgrave Macmillan.

De Vos, A., Dujardin, J-M., Gielens, T. \& Meyers, C. (2016). Developing sustainable careers across the lifespan. European Social Fund Network on 'Career and AGE (Age, Generations, Experience). Springer International.

Dean, H. (2007). The ethics of welfare-to-work. Policy \& Politics, 35(4), 573-589. https://doi. org/10.1332/030557307782453029.

Dean, H., Bonvin, J.-M., Vielle, P., \& Farvaque, N. (2005). Developing capabilities and rights in welfareto-work policies. European Societies, 7(1), 3-26. https://doi.org/10.1080/1461669042000327009.

Deeming, C. (2015). Foundations of the workfare state: Reflections on the political transformation of the welfare state in Britain. Social Policy \& Administration, 49(7), 862-886. https://doi.org/10.1111/ spol.12096.

Deneulin, S. (2011). Development and the limits of Amartya Sen's the idea of justice. Third World Quarterly, 32(4), 787-797. https://doi.org/10.1080/01436597.2011.567008.

Deneulin, S. (2014). Constructing new policy narratives: The capability approach as normative language. In G. A. Cornia \& F. Stewart (Eds.), Human development (pp. 45-63). Oxford University Press.

Dwyer, P., \& Wright, S. (2014). Universal Credit, ubiquitous conditionality and its implications for social citizenship. Journal of Poverty and Social Justice, 22(1), 27-35. https://doi.org/10.1332/17598 $2714 X 13875305151043$.

Dyke, A., Heinrich, C. J., Mueser, P. R., Troske, K. R., \& Kyung-Seong, J. (2006). The effects of welfareto-work program activities on labor market outcomes. Journal of Labor Economics, 24(3), 567-607. https://doi.org/10.1086/504642.

Egdell, V., \& Graham, H. (2017). A capability approach to unemployed young people's voice and agency in the development and implementation of employment activation policies. Social Policy \& Administration, 51(7), 1191-1209. https://doi.org/10.1111/spol.12262.

Egdell, V., \& McQuaid, R. (2016). Supporting disadvantaged young people into work: Insights from the Capability Approach. Social Policy \& Administration, 50(1), 1-18. https://doi.org/10.1111/ spol.12108.

European Commission. (2019). Evaluation of the Council Recommendation on the integration of the long-term unemployed into the labour market. Commission of the European Union. 
Finn, D., \& Schulte, B. (2008). "Employment First": Activating the British welfare state. In W. Eichhorst, O. Kaufmann, \& R. Konle-Seidl (Eds.), Bringing the jobless into work? Experiences with activation schemes in Europe and the US (pp. 297-344). Springer.

Fletcher, D. R. (2007). A culture of worklessness? Historical insights from the Manor and Park area of Sheffield. Policy \& Politics, 35(1), 65-85. https://doi.org/10.1332/030557307779657748.

Fuertes, V., \& Lindsay, C. (2016). Personalization and street-level practice in activation: The case of the UK's Work Programme. Public Administration, 94(2), 526-541. https://doi.org/10.1111/ padm.12234.

Fugate, M., Kinicki, A. J., \& Ashforth, B. E. (2004). Employability: A psycho-social construct, its dimensions, and applications. Journal of Vocational Behavior, 65(1), 14-38. https://doi.org/10.1016/j. jvb.2003.10.005.

Hall, D. T. (2004). The protean career: A quarter century journey. Journal of Vocational Behaviour, 65(1), 1-13. https://doi.org/10.1016/j.jvb.2003.10.006.

Hirschi, A. (2012). The career resources model: An integrative framework for career counsellors. British Journal of Guidance and Counselling, 40(4), 369-383. https://doi.org/10.1080/03069 885.2012.700506.

Hollywood, E., Egdell, V., McQuaid, R., \& Michel-Schertges, D. (2012). Methodological issues in operationalising the capability approach in empirical research: An example of cross-country research on youth unemployment in the EU. Social Work and Society, 10(1), 1-20.

Hooley, T., Sultana, R., \& Thomsen, R. (2017). The neoliberal challenge to career guidance: Mobilising research, policy and practice around social justice. In T. Hooley, R. Sultana, \& R. Thomsen (Eds.), Career guidance for social justice: Contesting neoliberalism (pp. 1-28). Routledge.

Ingold, J., \& Stuart, M. (2015). The demand-side of active labour market policies: A regional study of employer engagement in the work programme. Journal of Social Policy, 44(3), 443-462. https:// doi.org/10.1017/S0047279414000890.

Irving, B. (2005). Social justice: A context for career education and guidance. In B. Irving \& B. Malik (Eds.), Critical reflections on career education and guidance: Promoting social justice within a global economy (pp. 10-24). Routledge.

Kidd, J. M. (2006). Understanding career counselling: Theory, research and practice. Sage.

Kluve, J. (2010). The effectiveness of European active labor market programs. Labour Economics, 17(6), 904-918. https://doi.org/10.1016/j.labeco.2010.02.004.

Laruffa, F. (2019). Towards a post-neoliberal social policy? Social investment versus capability approach. Momentum Quarterly - Zeitschrift für sozialen Fortschritt, 7(4), 171-187.

Lindsay, C. (2014). Work first versus human capital development in employability programs. In U. C. Klehe \& E. van Hooft (Eds.), Oxford handbook of job loss and job search (pp. 561-574). Oxford University Press.

Lindsay, C., McQuaid, R., \& Dutton, M. (2007). New approaches to employability in the UK: Combining "human capital development" and "work first" strategies? Journal of Social Policy, 36(4), 539-560. https://doi.org/10.1017/S0047279407001171.

Lødemel, I., \& Trickey, H. (2001). An offer you can't refuse: Workfare in international perspective. Policy Press.

Mackenzie Davey, K. (2020). Organizational career development theory: Weaving individuals, organizations, and social structures. In P. J. Robertson, T. Hooley, \& P. McCash (Eds.), The Oxford handbook of career development. Oxford University Press.

Maree, J. G. (2010). Brief overview of the advancement of postmodern approaches to career counselling. Journal of Psychology in Africa, 20(3), 361-367. https://doi.org/10.1080/14330 237.2010.10820387.

Martin, J. P., \& Grubb, D. (2002). What works and for whom: A review of OECD Countries' experiences with active labour market policies. Swedish Economic Policy Review, 8(2), 9-56.

McArdle, S., Waters, L. E., Briscoe, J. P., \& Hall, D. T. (2007). Employability during unemployment: Adaptability, career identity and human and social capital. Journal of Vocational Behavior, 71(2), 247-264. https://doi.org/10.1016/j.jvb.2007.06.003.

McMahon, M., \& Patton, W. (2006). Career counselling: Constructivist approaches. Routledge.

McQuaid, R., \& Fuertes, V. (2014). Sustainable integration of the long term unemployed: From Work First to Career First. In C. Larsen, et al. (Eds.), Sustainable economy and sustainable employment (pp. 359-373). Rainer Hampp Verlag.

McQuaid, R., Fuertes, V., \& Richard, A. (2010). How can parents escape from recurrent poverty? Joseph Rowntree Foundation. 
McQuaid, R. W., \& Lindsay, C. (2005). The concept of employability. Urban Studies, 42(2), 197-219. https://doi.org/10.1080/0042098042000316100.

Mead, L. M. (2003). Welfare caseload change: An alternative approach. Policy Studies Journal, 31(2), 163-185. https://doi.org/10.1111/1541-0072.00010.

National Audit Office. (2007). Sustainable employment: supporting people to stay in work and advance. The Stationery Office.

Nunn, A. (2019). Do employment services need to be neoliberal? In T. Hooley, R. G. Sultana, \& R. Thomsen (Eds.), Career guidance for emancipation: Reclaiming justice for the multitude (pp. 166-182). Routledge.

Nussbaum, M. C. (2011). Creating capabilities. Harvard University Press.

OECD. (2004). Career guidance: A handbook for policy makers. Organisation for Economic Co-operation and Development/European Commission.

Orton, M. (2011). Flourishing lives: The capabilities approach as a framework for new thinking about employment, work and welfare in the 21st century. Work, Employment \& Society, 25(2), 352-360. https://doi.org/10.1177/0950017011403848.

Patrick, R. (2012). Work as the primary "duty" of the responsible citizen: A critique of this work-centric approach. People, Place and Policy Online, 6(1), 5-15. https://doi.org/10.3351/ppp.0006.0001.0002.

Peck, J., \& Theodore, N. (2001). Exporting workfare/importing welfare-to-work: Exploring the politics of Third Way policy transfer. Political Geography, 20(4), 427-460. https://doi.org/10.1016/S0962 $-6298(00) 00069-X$.

Picard, F., Olympio, N., Masdonati, J., \& Bangali, M. (2015). Justice sociale et orientation scolaire: l'éclairage de l'approche par les «capabilités» d'Amartya Sen. L'Orientation Scolaire et Professionnelle, 44(1), 23-45. https://doi.org/10.4000/osp.4515.

Plant, P., \& Haug, E. H. (2018). Unheard: the voice of users in the development of quality in career guidance services. International Journal of Lifelong Education, 37(3), 372-383. https://doi. org/10.1080/02601370.2018.1485058.

Ray, K., Hoggart, L., Taylor, R., Vegeris, S., \& Campbell-Barr, V. (2009). Rewarding responsibility? Long-term unemployed men and the welfare-to-work agenda. Environment and Planning C: Government and Policy, 27(6), 975-990. https://doi.org/10.1068/c0852.

Rees, J., Whitworth, A., \& Carter, E. (2014). Support for all in the UK Work Programme? Differential payments, same old problem. Social Policy \& Administration, 48(2), 221-239. https://doi. org/10.1111/spol.12058.

Roberts, K. (2009). Opportunity structures then and now. Journal of Education \& Work, 22(5), 355-368. https://doi.org/10.1080/13639080903453987.

Robertson, P. J. (2015). Towards a capability approach to careers: Applying Amartya Sen's thinking to career guidance and development. International Journal for Educational and Vocational Guidance, 15(1), 75-88. https://doi.org/10.1007/s10775-014-9280-4.

Robertson, P. J., \& Egdell, V. (2018). A capability approach to career development: An introduction and implications for practice. Australian Journal of Career Development, 27(3), 119-126. https://doi. org/10.1177/1038416217704449.

Rogers, C. R. (1951). Client-centered therapy. Its current practice, implications, and theory. Houghton Mifflin.

Savickas, M. L., \& Porfeli, E. J. (2012). Career adapt-abilities scale: Construction, reliability, and measurement equivalence across 13 countries. Journal of Vocational Behavior, 80(3), 661-663. https:// doi.org/10.1016/j.jvb.2012.01.011.

Schröer, R. (2015). Employability versus capability: European strategies for young people. In H. U. Otto, et al. (Eds.), Facing trajectories from school to work (pp. 361-386). Springer.

Sen, A. (1985a). Commodities and capabilities. Elsevier.

Sen, A. (1985b). Well-being, agency and freedom: The Dewey lectures 1984. The Journal of Philosophy, 82(4), 169-221. https://doi.org/10.2307/2026184.

Shildrick, T., \& MacDonald, R. (2012). Poverty and insecurity: Life in low-pay, no-pay Britain. Policy Press.

Shildrick, T., MacDonald, R., Furlong, A., Rodan, J., \& Crow, R. (2012b). Are 'cultures of worklessness' passed down the generations?. Joseph Rowntree Foundation.

Sinfield, A. (2001). Benefits and research in the labour market. European Journal of Social Security, 3(3), 209-235. https://doi.org/10.1023/A:1014729706715. 
Sol, E., \& Hoogtanders, Y. (2005). Steering by contract in the Netherlands: New approaches to labour market integration. In E. Sol \& M. Westerveld (Eds.), Contractualism in employment services (pp. 139-166). Kluwe.

Sultana, R. G., \& Watts, A. G. (2006). Career guidance in public employment services across Europe. International Journal for Educational and Vocational Guidance, 6(1), 29-46. https://doi. org/10.1007/s10775-006-0001-5.

Super, D. L. (1980). A life-span, life-space approach to career development. Journal of Vocational Behavior, 16(3), 282-298.

Super, D. E., Savickas, M. L., \& Super, C. M. (1996). The life-span, life-space approach to careers. In D. Brown, L. Brooks, \& Associates (Eds.), Career choice \& development (pp. 121-177). Jossey-Bass.

Van Berkel, R., \& Borghi, V. (2007). New modes of governance in activation policies. International Journal of Sociology and Social Policy, 27(7/8), 277-286. https://doi.org/10.1108/01443330710773854.

Watts, A. G. (2008). Career guidance and public policy. In J. A. Athanasou \& R. van Esbroeck (Eds.), International handbook of career guidance (pp. 341-353). Springer.

Watts, A. G., \& Sultana, R. (2004). Career guidance policies in 37 countries: Contrasts and common themes. International Journal for Vocational and Educational Guidance, 4(2-3), 105-122. https:// doi.org/10.1007/s10775-005-1025-y.

Wright, S., \& Patrick, R. (2019). Welfare conditionality in lived experience: Aggregating qualitative longitudinal research. Social Policy and Society, 18(4), 597-613. https://doi.org/10.1017/S147474641 9000204.

Yorke, M. (2006). Employability in higher education: What it is-what it is not. The Higher Education Academy.

Zimmermann, B. (2006). Pragmatism and the capability approach. European Journal of Social Theory, 9(4), 467-484. https://doi.org/10.1177/1368431006073014.

Publisher's Note Springer Nature remains neutral with regard to jurisdictional claims in published maps and institutional affiliations. 